\title{
Effect of High Levels of Impurity Calcium on the Electrochemical Performance of Spinel $\mathrm{LiMn}_{2} \mathrm{O}_{4}$
}

\author{
Xing ZOU ${ }^{\mathrm{a}}$, Peng WU ${ }^{\mathrm{b}}$, Hai-Chao XIE
}

State Key Laboratory of Advanced Metallurgy, School of Metallurgical and Ecological Engineering, University of Science and Technology Beijing, Beijing, 100083, China

azou_duanduan@sina.com, ${ }^{b} 476718314 @ q q . c o m$

Keywords: Solid-phase synthesis, Impurity, Calcium, Spinel $\mathrm{LiMn}_{2} \mathrm{O}_{4}$, Electrochemical properties

\begin{abstract}
Spinel $\mathrm{LiMn}_{2} \mathrm{O}_{4}$ was synthesized by solid-state method,using $\mathrm{Mn}_{2} \mathrm{O}_{3}$ as manganese source. By X-ray diffraction, scanning electron microscope and electrochemical performance test, effects of impurity calcium from manganese source.ie. $\mathrm{MnCO}_{3}$ on the electrochemical properties of spinel $\mathrm{LiMn}_{2} \mathrm{O}_{4}$ weresystematically studied. The results showed that allsamples with different contents of impurity calciumwere indexed to spinel phase with the cubic space of $\mathrm{Fd} 3 \mathrm{~m}$, and no impurity phase was detected; the particle size and morphology of sampleswere not obviously different; when the contents of impuritywere low, the first charge-discharge capacity remained almost unchanged with the increase of calcium; and in contrast, itdistinctlydecreased. The results also showed that the cycle-stability of $\mathrm{LiMn}_{2} \mathrm{O}_{4}$ was improved collaboratively.
\end{abstract}

With the rapid development of the global economy, it is bound to increase consumption such as the oil and other fossil fuel resources. The lithium-ion secondary battery, called "green power", has attracted much more attention due to the most prominent features such as its small, lightweight, long working hours, long cycle life, no memory effect, fast charge and discharge, low self-discharge and environmental friendly etc.[1,2]. Owing to the serious attenuation of charge-discharge reversible capacity, instability and other shortcomings on electrochemical properties of the spinel $\mathrm{LiMn}_{2} \mathrm{O}_{4}$, its development is facing with lots of restriction [3, 4, 5]. Much work has been done in an effort to improve the electrochemical performance of the spinel $\mathrm{LiMn}_{2} \mathrm{O}_{4}$ by suppressing Jahn-Teller distortion. $\mathrm{Ma}[6]$ studied the influence of different manganese sources on the performance of spinel $\mathrm{LiMn}_{2} \mathrm{O}_{4}$, finding that the spinel $\mathrm{LiMn}_{2} \mathrm{O}_{4}$ synthesized by $\mathrm{Mn}_{2} \mathrm{O}_{3}$ exhibited dense particles, uniform distribution and the most excellent electrochemical performance. The price of high-purity $\mathrm{Mn}_{2} \mathrm{O}_{3}$ is significantly higher than electrolytic manganese dioxide (EMD), but the value of the industrial-grade $\mathrm{Mn}_{2} \mathrm{O}_{3}$ is lower than EMD. Industrial-grade $\mathrm{Mn}_{2} \mathrm{O}_{3}$ contains large amounts of impurities such as $\mathrm{Ca}^{2+}, \mathrm{Mg}^{2+}, \mathrm{SiO}_{3}{ }^{2-}, \mathrm{SO}_{4}{ }^{2-}, \mathrm{K}^{+}, \mathrm{Na}^{+}$. Peng[7] discussed the electrochemical properties of the spinel $\mathrm{LiMn}_{2} \mathrm{O}_{4}$ prepared by $\mathrm{Mn}_{2} \mathrm{O}_{3}$ that containing $\mathrm{K}^{+}$, showing that its first charge-discharge capacity drastically decreased and the capacity retention also declined with the increase of $\mathrm{K}^{+}$. Xie[8] researched the electrochemical properties of the spinel $\mathrm{LiMn}_{2} \mathrm{O}_{4}$ that containingCa ${ }^{2+}$ and $\mathrm{Mg}^{2+}$, illustrating that morphology of the samples was improved and cycle performance was enhanced with the increase of $\mathrm{Ca}^{2+}$ and $\mathrm{Mg}^{2+}$. However, no relevant literatures are reported on the effects of $\mathrm{Mn}_{2} \mathrm{O}_{3}$ that containing high contents of impurity calcium on the electrochemical properties of the spinel $\mathrm{LiMn}_{2} \mathrm{O}_{4}$. In this paper, spinel $\mathrm{LiMn}_{2} \mathrm{O}_{4}$ is synthesized by solid-state method, using $\mathrm{Mn}_{2} \mathrm{O}_{3}$ that containing high contents of impurity calcium as manganese source, and the electrochemical properties of the batteries and the microscopic appearance of the spinel $\mathrm{LiMn}_{2} \mathrm{O}_{4}$ will be studied.

\section{Experiment}

\subsection{Preparation of Spinel $\mathrm{LiMn}_{2} \mathrm{O}_{4}$ and Battery}

All the manganese sources were prepared in laboratory. $\mathrm{LiCO}_{3}$ is produced by Shanghai $\mathrm{Li}$ Industrial Company Limited. Different manganese sources and $\mathrm{LiCO}_{3}$ were weighed in $\mathrm{Li} / \mathrm{Mn}$ at molar ratios of 1:2 and then completely mixed in an agate mortar for grinding. Then took the 
mixture into a corundum crucible and heated to $560{ }^{\circ} \mathrm{C}$ at $3{ }^{\circ} \mathrm{C} / \mathrm{min}$ in air, $5 \mathrm{~h}$ later raised to $780{ }^{\circ} \mathrm{C}$ at the same heating rate, after 48 hours heat preservation, the raw materials were cooled down to room temperature, then passed through 200 mesh sieve, finally achieved the spinel $\mathrm{LiMn}_{2} \mathrm{O}_{4}$ as cathode material. The cathode material, the conductive agent (acetylene black) and the polytetrafluoroethylene (PTFE) emulsion were uniformly mixed according to the mass ratio of $85: 10: 5$ accurately, and dried in an oven for $24 \mathrm{~h}$ at $110^{\circ} \mathrm{C}$. Subsequently the mixture was pressed into $5 \sim 10 \mathrm{mg}$ weight, $0.1 \mathrm{~mm}$ thick slices, and then it was rushed into a wafer with a $\varphi 8$ punch, thus the positive films were obtained. The lithium tablets were used as anode materials and 1.0M commercial $\mathrm{LiPF}_{6}$ in DMC: EC: DEC (1:1:1 in volume) as the electrolyte. And then they are assembled the CR2032 button-type batteries in an argon-filled glove-box.

\subsection{Characterization and Electrochemical Measurements}

The crystal structure of the materials was analyzed by an X-ray diffraction operated at $40 \mathrm{KV}$ and $150 \mathrm{~mA}$ from $10^{\circ}$ to $90^{\circ}$ (Rigaku, D/Max-RB, Japan) with a wavelength of $\mathrm{Cu} \mathrm{K}_{\alpha}(\lambda=0.15406 \mathrm{~nm})$. Scanning electron microscopy (SEM) was obtained through a spectrometer (SEM, Hitachi S-3400N Japan). Electrical performance test was carried out using a NEWARE tester, Charge-discharge cycles were carried out at $0.1 \mathrm{C}$ in CR2023 coin cells, with a potential range between 3.0 and $4.3 \mathrm{~V}$ at room temperature.

\section{Results and Discussion}

\subsection{Effect of Manganese Source with Low Levels of Calcium on the Performance of Spinel} $\mathrm{Li}_{1.06} \mathrm{Mn}_{2} \mathrm{O}_{4}$

Table 1 The contents of calcium in $\mathrm{Mn}_{2} \mathrm{O}_{3}$ and corresponding electrical properties of $\mathrm{Li}_{1.06} \mathrm{Mn}_{2} \mathrm{O}_{4}$ as cathode materials

\begin{tabular}{|c|c|c|c|c|}
\hline Samples & $\begin{array}{c}\mathrm{Ca}^{2+} \\
\left(\mu \mathrm{g}^{-1}\right)\end{array}$ & $\begin{array}{c}\text { The first charge } \\
\text { capacity ofLi } \\
\left(\mathrm{mA} \cdot \mathrm{h}_{1.06} \mathrm{~g}^{-1}\right)\end{array}$ & $\begin{array}{c}\text { The first discharge } \\
\text { capacity of }\end{array}$ & $\begin{array}{c}\text { Discharge capacity } \\
\text { retention rate after } \\
\text { 50 cycles (\%) }\end{array}$ \\
\hline $\begin{array}{c}\text { High } \\
\text { purity }\end{array}$ & 49 & 133.910 & 128.487 & 89.15 \\
\hline $1-1$ & 492 & 133.229 & 127.065 & 88.95 \\
\hline $1-2$ & 2240 & 132.483 & 126.902 & 90.68 \\
\hline $1-3$ & 4560 & 131.271 & 126.191 & 92.17 \\
\hline $1-4$ & 7747 & 129.825 & 125.035 & 92.93 \\
\hline
\end{tabular}

Samples with low contents of $\mathrm{Ca}^{2+}$ are listed in Table 1.

Figure 1 shows the first charge-discharge curves of $\mathrm{Li}_{1.06} \mathrm{Mn}_{2} \mathrm{O}_{4}$ containing $\mathrm{Ca}^{2+}$ at lower range. As shown in the figure, all the curves have two distinct charge-discharge platforms at $4.0 \mathrm{~V}$ and $4.1 \mathrm{~V}$, illustrating that all the samples undergo two reversible electrochemical reactions in the vicinity of the two electrodes, the former corresponds to the escape of lithium-ions from the tetrahedral 8a position, the latter corresponds to the intercalation of lithium-ions from the empty octahedral 16c position. The first charge-discharge capacities of $\mathrm{Li}_{1.06} \mathrm{Mn}_{2} \mathrm{O}_{4}$ remain almost unchanged with the increase of $\mathrm{Ca}^{2+}$.

Figure 2(a) reveals cycling-curves of discharge-capacity of spinel $\mathrm{Li}_{1.06} \mathrm{Mn}_{2} \mathrm{O}_{4}$ after 50 cycles. It can be seen from the figure that cyclic stability of lithium-rich $\mathrm{Li}_{1.06} \mathrm{Mn}_{2} \mathrm{O}_{4}$ is improved with the increase of impurity $\mathrm{Ca}^{2+}$, it is the reason that impurity $\mathrm{Ca}^{2+}$ replaces part of $\mathrm{Mn}^{3+}(16 \mathrm{~d})$ which results in improvement of morphology and more dispersion of the particles. So the electrolyte keeps in contact with the active materials more fully. 

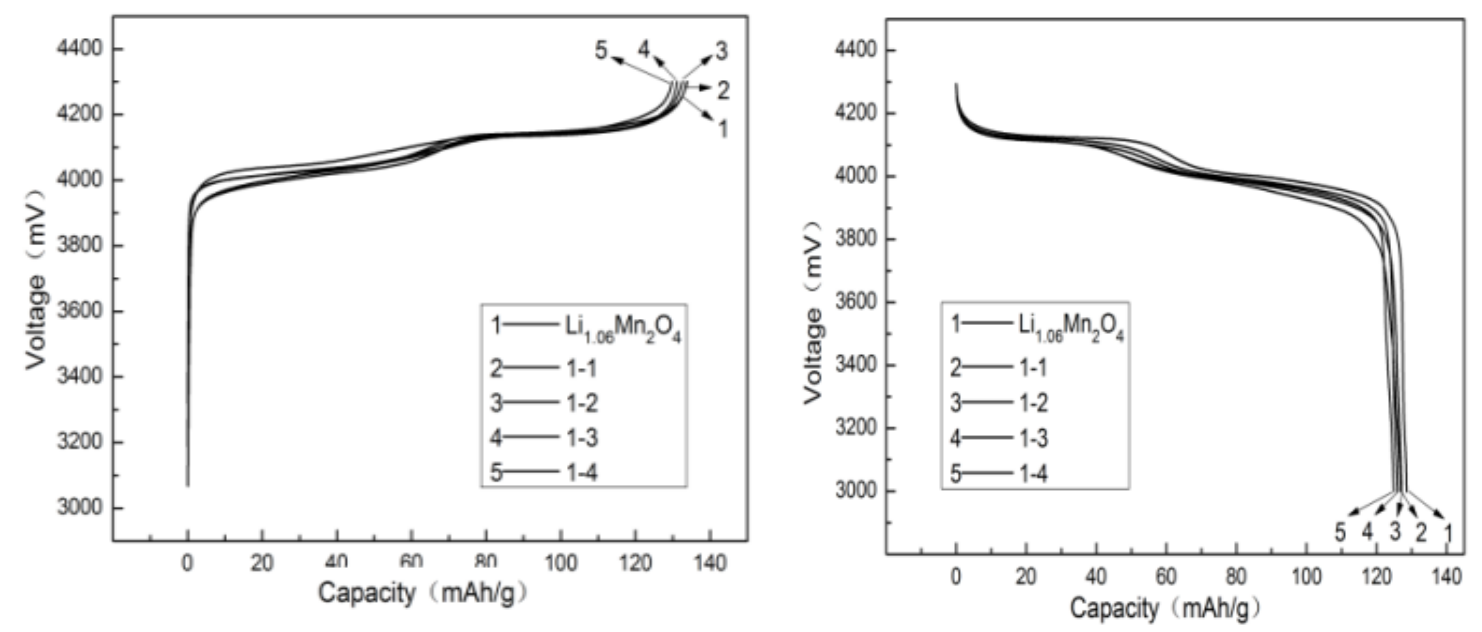

Figure 1 The initial charge-discharge curves of synthetic $\mathrm{Li}_{1.06} \mathrm{Mn}_{2} \mathrm{O}_{4}$ with low levels of calcium

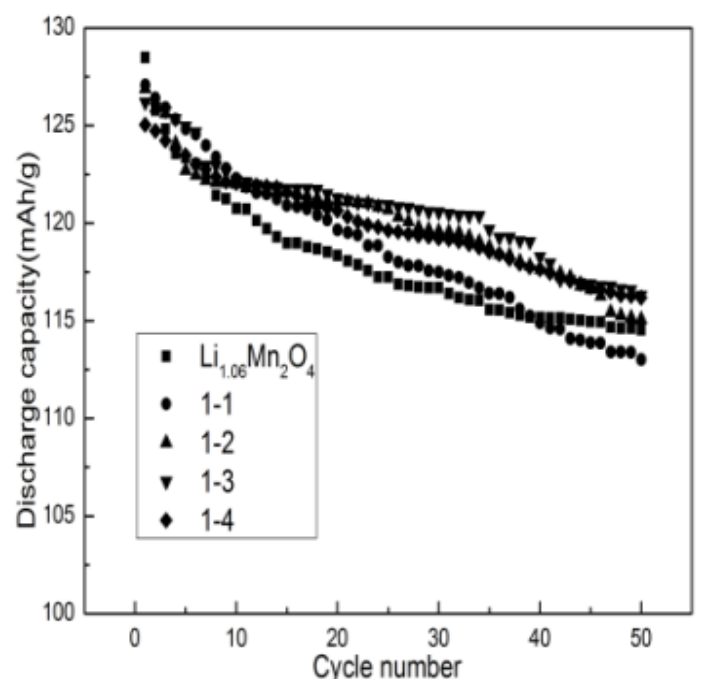

(a)

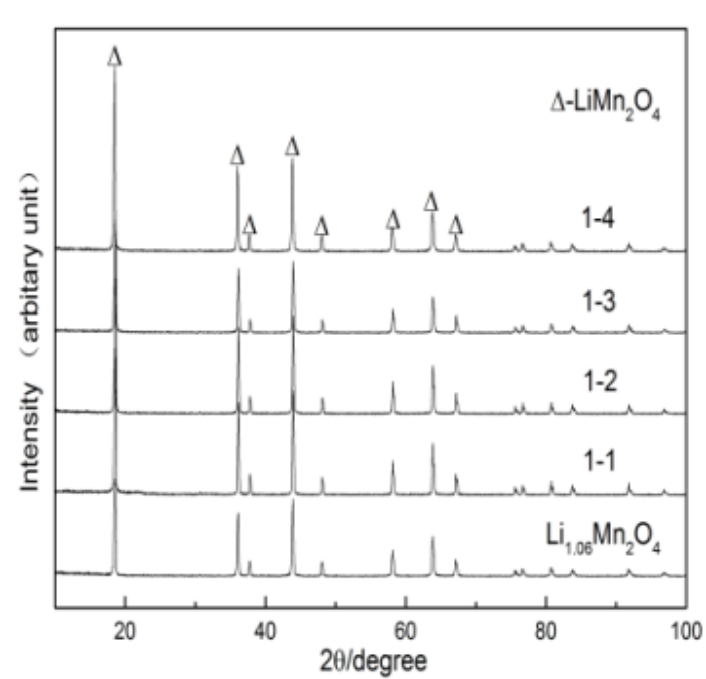

(b)

Figure 2 The discharge-cycle characteristics (a) and XRD patterns (b) of synthetic $\mathrm{Li}_{1.06} \mathrm{Mn}_{2} \mathrm{O}_{4} \mathrm{with}$ low levels of calcium

Figure 2(b) is the XRD patterns of synthetic lithium-rich $\mathrm{Li}_{1.06} \mathrm{Mn}_{2} \mathrm{O}_{4}$ with low contents of calcium. All synthetic samples are indexed to spinel phase with the cubic space of Fd3m, which are in agreement with that of standard spinel $\mathrm{LiMn}_{2} \mathrm{O}_{4}$. No peaks of calcium compounds are detected in each sample with the increase of calcium, which may be related to the fact that the content of impurity calcium is small. Additionally, the spinel lattice sizes of the as-prepared samples calculated according to the XRD patterns are from $0.8249 \mathrm{~nm}$ to $0.8245 \mathrm{~nm}$, their changes are not obvious.

Figure 3 is the SEM of the $\mathrm{Li}_{1.06} \mathrm{Mn}_{2} \mathrm{O}_{4}$ containing low levels of $\mathrm{Ca}^{2+}$. It can be seen from the figure that all samples display dense spherical particles. The cathode materialssynthesized by $\mathrm{MnCO}_{3}$ also exhibit fine and evenly distributed particles, but there is a certain amount of agglomeration. Particles progressively become much larger, agglomeration is improved with the increase of $\mathrm{Ca}^{2+}$. That is especially obvious for sample 1-4, the particles become more dispersed and the agglomeration is improved more distinctly. 

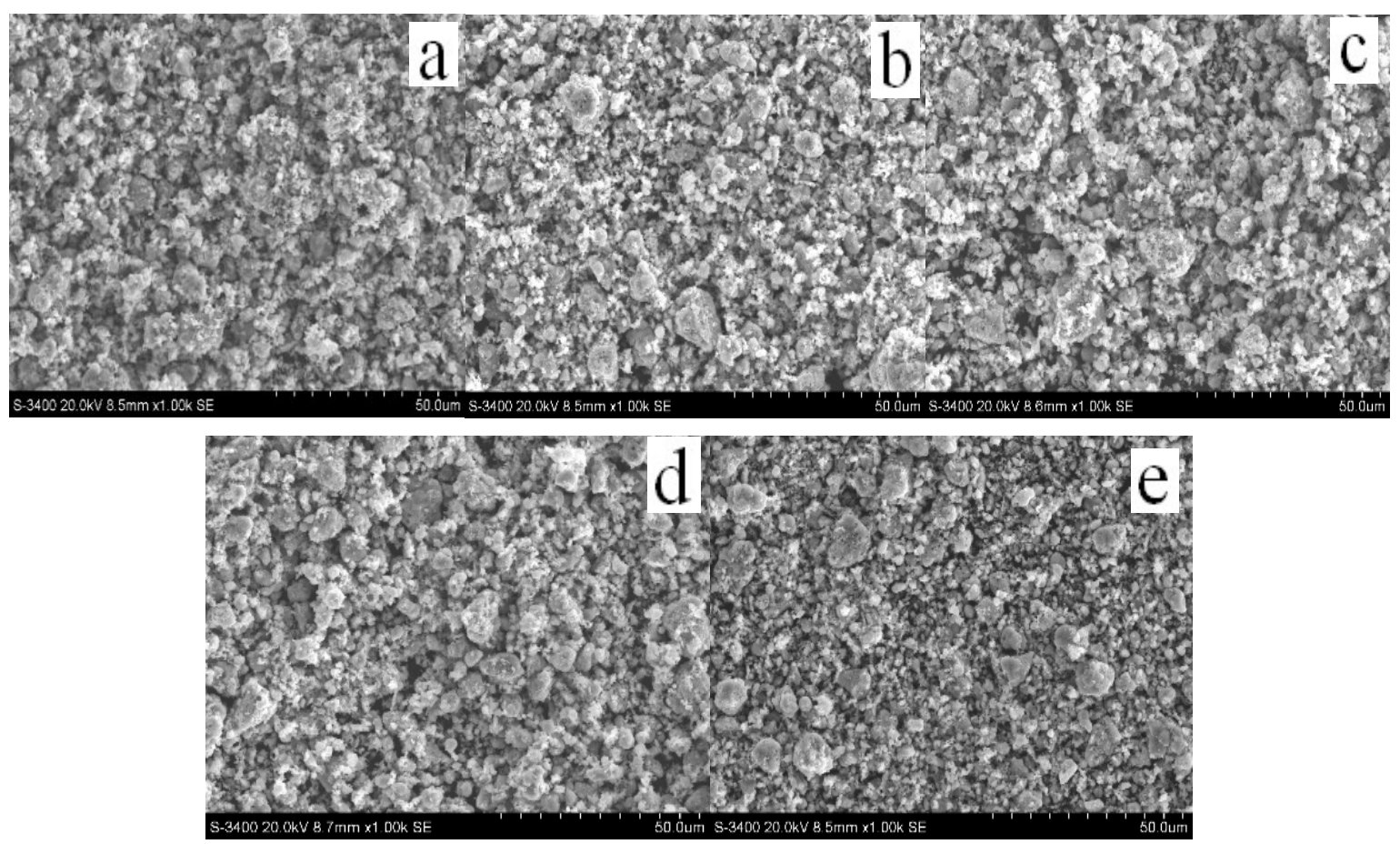

Figure 3 The SEM of synthetic $\mathrm{Li}_{1.06} \mathrm{Mn}_{2} \mathrm{O}_{4}$ with low levels of calcium

$$
\text { (a: } \mathrm{Li}_{1.06} \mathrm{Mn}_{2} \mathrm{O}_{4} \text {, b:1-1, c:1-2, d:1-3, e:1-4) }
$$

\subsection{Effect of Manganese Source with High Levels of Calcium on the Performance of Spinel $\mathrm{LiMn}_{2} \mathrm{O}_{4}$}

Table 2 The contents of calcium in $\mathrm{Mn}_{2} \mathrm{O}_{3}$ and corresponding electrical properties of $\mathrm{LiMn}_{2} \mathrm{O}_{4}$ as cathode materials

\begin{tabular}{|c|c|c|c|c|}
\hline Samples & $\begin{array}{c}\mathrm{Ca}^{2+} \\
\left(\mu \mathrm{g}^{-1}\right)\end{array}$ & $\begin{array}{c}\text { The first charge } \\
\text { capacity of } \\
\mathrm{LiMn}_{2} \mathrm{O}_{4}\left(\mathrm{~mA} \cdot \mathrm{h}^{-1} \mathrm{~g}^{-1}\right)\end{array}$ & $\begin{array}{c}\text { The first discharge } \\
\text { capacity of } \\
\mathrm{LiMn}_{2} \mathrm{O}_{4}\left(\mathrm{~mA} \cdot \mathrm{h}^{-1}\right)\end{array}$ & $\begin{array}{c}\text { Discharge capacity } \\
\text { retention rate after } \\
50 \text { cycles }(\%)\end{array}$ \\
\hline $\begin{array}{c}\text { High } \\
\text { purity }\end{array}$ & 20.85 & 137.939 & 126.856 & 69.47 \\
\hline $2-1$ & 7640.99 & 122.035 & 115.900 & 72.38 \\
\hline $2-2$ & 8659.93 & 120.805 & 114.276 & 82.42 \\
\hline $2-3$ & 11336.00 & 104.561 & 101.130 & 84.64 \\
\hline $2-4$ & 15103.58 & 98.300 & 97.179 & 86.89 \\
\hline
\end{tabular}

Samples with high contents of $\mathrm{Ca}^{2+}$ are listed in Table 2.

Figure 4(a) is the first charge-discharge curves of $\mathrm{LiMn}_{2} \mathrm{O}_{4}$ with high contents of $\mathrm{Ca}^{2+}$. It can be seen from the figure that all the charge-discharge curves have two obvious platforms, corresponding to the insertion and prolapse of lithium-ions respectively. With the increase of calcium, it appears seriously damped for the first charge-discharge capacity of $\mathrm{LiMn}_{2} \mathrm{O}_{4}$. Especially, first charge-discharge capacity decays obviously for sample 2-4. The severe capacity loss is mainly due to the decrease of active substance $\mathrm{Mn}^{3+}$ of the spinel material. Replacement of $\mathrm{Mn}^{3+}$-ions by $\mathrm{Ca}^{2+}$-ionsforms $\mathrm{LiMn}_{2-\mathrm{x}} \mathrm{Ca}_{\mathrm{x}} \mathrm{O}_{4}$, which results in decrease of active-ions $\mathrm{Mn}^{3+}$ and obstacle of $\mathrm{Li}^{+}$ diffusion in the process of charge-discharge. To reach the charge balance, the amount of $\mathrm{Mn}^{4+}$-ion inevitably increases in the spinel structure. The increased $\mathrm{Li} / \mathrm{Mn}$ ratio suggests the $\mathrm{Li}^{+}$-ions would diffuse into the octahedral sites to occupy the $\mathrm{Mn}$ sites to form $\mathrm{LiMn}_{2-\mathrm{y}} \mathrm{Li}_{\mathrm{y}} \mathrm{O}_{4}{ }^{[9]}$. And the increase of the ratio of $\mathrm{Mn}^{4+} / \mathrm{Mn}^{3+}$ in the spinel $\mathrm{LiMn}_{2} \mathrm{O}_{4}$ would reduce the spinel lattice size because the radius of $\mathrm{Mn}^{3+}$-ion is larger than that of $\mathrm{Mn}^{4+}$-ion. As a result, the charge-discharge capacity decreases 
along with it.

Figure 4(b) is the cyclic performance-curves of $\mathrm{LiMn}_{2} \mathrm{O}_{4}$ containing high levels of $\mathrm{Ca}^{2+}$ at room temperature. It can be obtained from figure that the samples with high levels of $\mathrm{Ca}^{2+}$-ion exhibit more excellent cycle stability than the sample without $\mathrm{Ca}^{2+}$-ion (high-purity). This is mainly because the discharge capacity can be affected by the relative crystallinity of synthesized samples, while the $\mathrm{Ca}^{2+}$-ion will have a large impact on the crystallization quality. The adjunction of $\mathrm{Ca}^{2+}$-ion reduces the unit cell volume of the spinel $\mathrm{LiMn}_{2} \mathrm{O}_{4}$, and bond length of $\mathrm{Ca}-\mathrm{O}$ is stronger than $\mathrm{Mn}-\mathrm{O}$ on the basis of standard Gibbs energies, thereby the crystal structure is enhanced and Jahn-Teller is effectively suppressed. As a result, it is more conducive to deintercalation of the lithium-ions and the improvement of cycling performance of the samples.

Figure 5 is the XRD spectra of $\mathrm{LiMn}_{2} \mathrm{O}_{4}$ with high contents of calcium. It can be seen from the figure that all the diffraction peaks completely match with the cubic spinel structure with space group of Fd3m, indicating that the calcium substitution does not change the intrinsic spinel structure of $\mathrm{LiMn}_{2} \mathrm{O}_{4}$ (Joint Committee on Powder Diffraction Standards (JCPDS) no. 18-0736), in which lithium ions occupy the tetrahedral 8a sites, manganese ions occupy the octahedral $16 \mathrm{~d}$ sites, and oxygen ions occupy the 32e sites ${ }^{[11]}$. X-ray diffraction patterns also reveal that the materials are good crystallinity and no diffraction peak of impurity can be discovered. It is believed that $\mathrm{Ca}^{2+}$-ion completely occupies the $\mathrm{Mn}^{3+}$-ion (16d) site in $\mathrm{LiMn}_{2-\mathrm{x}} \mathrm{Ca}_{\mathrm{x}} \mathrm{O}_{4}$, which stabilizes the structures of the materials.

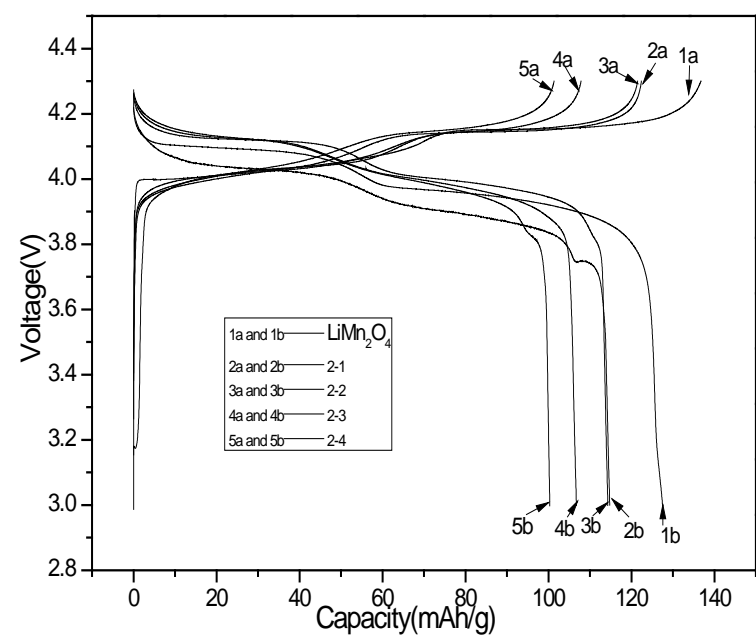

(a)

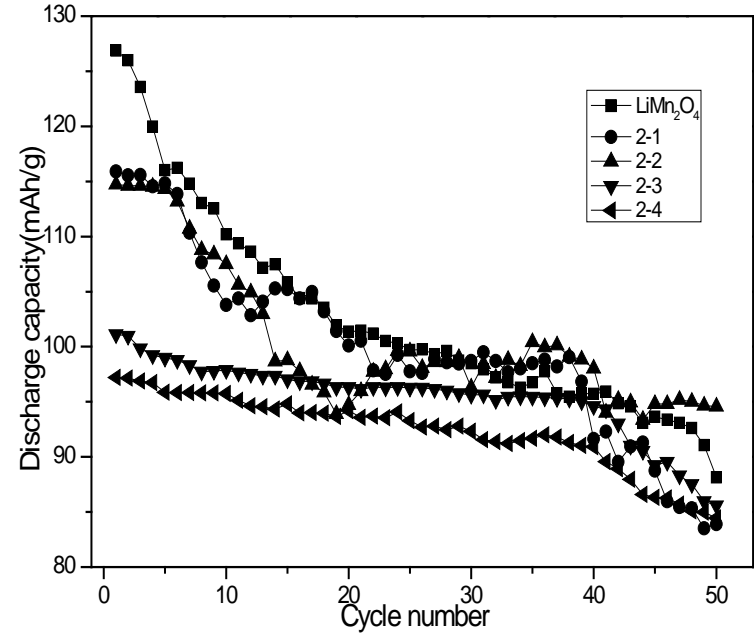

(b)

Figure 4 The initial charge-discharge curves (a) and cycle-stability curves (b) of $\mathrm{LiMn}_{2} \mathrm{O}_{4}$ with high levels of calcium

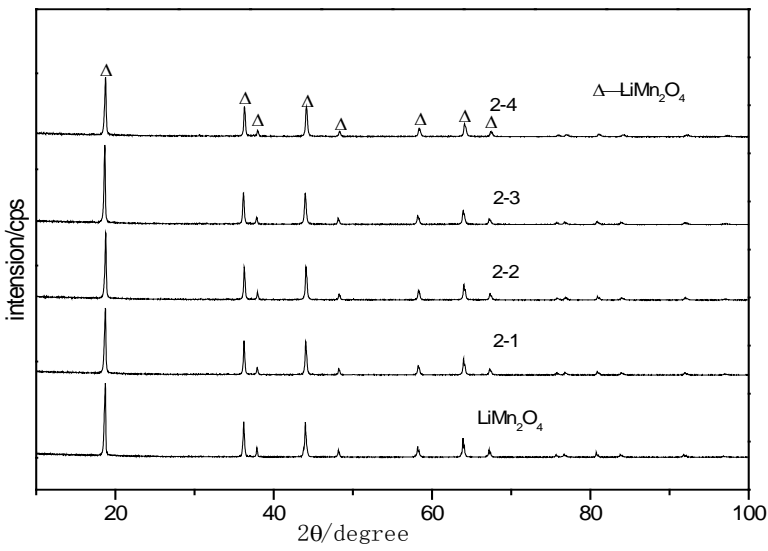

Figure 5 The XRD pattern of synthetic $\mathrm{LiMn}_{2} \mathrm{O}_{4}$ with high levels of calcium 


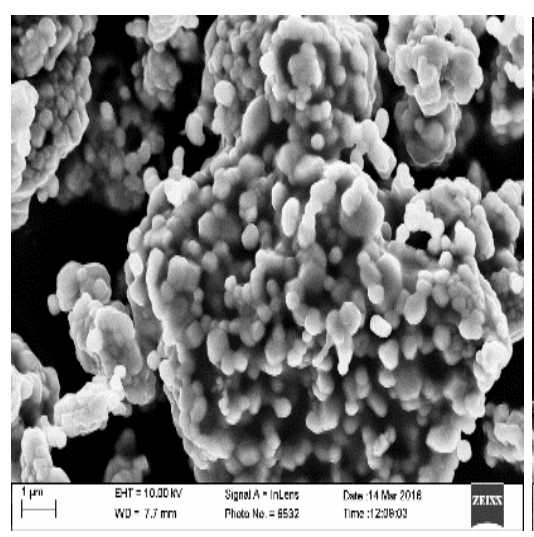

High purity

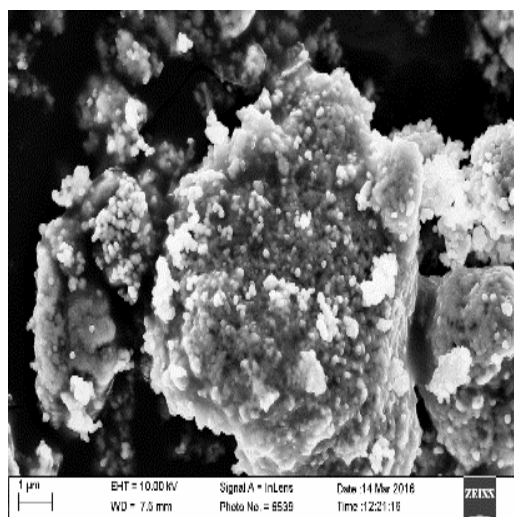

$2-1$

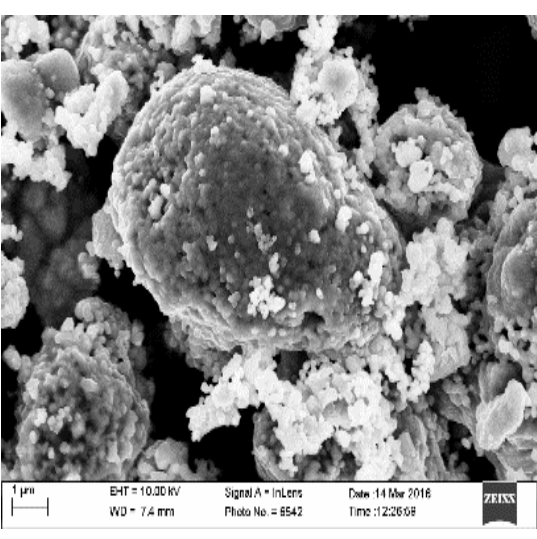

$2-2$

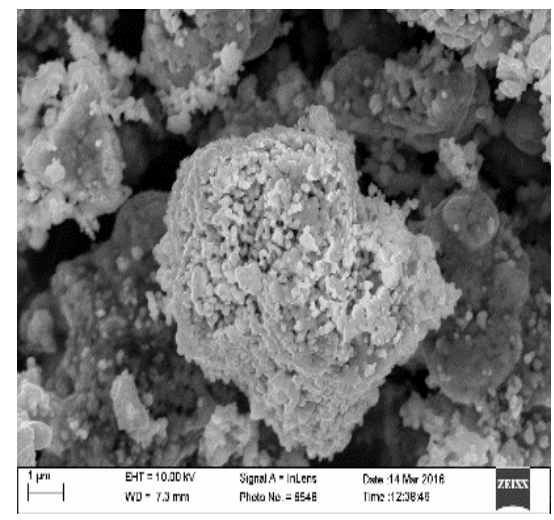

$2-3$

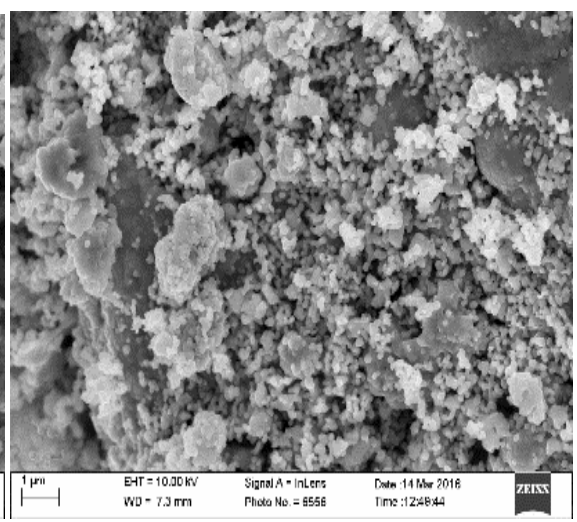

$2-4$

Figure 6The SEM of synthetic $\mathrm{LiMn}_{2} \mathrm{O}_{4}$ with high levels of calcium

Figure 6 is SEM images of the $\mathrm{LiMn}_{2} \mathrm{O}_{4}$ containing high levels of $\mathrm{Ca}^{2+}$. From the view of microstructure, all cathode materials present irregular-shaped particles and uneven particle size distribution. Furthermore, it is important to note that the substitution of $\mathrm{Ca}^{2+}$-ion contributes to improving the crystallization and decrease of the average microscopic particle size of obtained products. That is especially obvious for sample 2-4, the particles with good crystallization have more regular morphology, which leads to shortening the paths of prolapse-embedded of the lithium-ions and decrease of polarization effects of $\mathrm{Li}^{+}$-ions. Simultaneously, agglomeration of the electrode materials is improved and the particles become more small dense with the increase of $\mathrm{Ca}^{2+}$-ion. Additionally, the increase of specific surface area results in the more sufficient contact between the cathode material and theelectrolyte.

\section{Conclusions}

(1) The $\mathrm{Li}_{1.06} \mathrm{Mn}_{2} \mathrm{O}_{4}$ samples containing low contents of calcium are synthesized by solid-state method, using $\mathrm{Mn}_{2} \mathrm{O}_{3}$ as manganese source. The samples are indexed to spinel phase with the cubic space of Fd3m, small and distributed particles and no agglomeration. Particles become more dispersed with the increase of calcium. The first charge and discharge capacities of assembled batteries remain almost unchanged, and the efficiency of the first charge-discharge and the retention rate of 50 cycles are improved.

(2) The $\mathrm{LiMn}_{2} \mathrm{O}_{4}$ samples containing high contents of calcium are synthesized by solid-state method, using $\mathrm{Mn}_{2} \mathrm{O}_{3}$ as manganese source. The samples completely match with the cubic spinel structure with space group of Fd3m, particle size distribution is more discrete and there is a certain amount of agglomeration. The initial charge-discharge capacities emerge seriously attenuated with the increase of calcium, but stability of 50-cycles is significantly improved.

(3) Comprehensive results show that effects of manganese source with low contents of calcium on the electrochemical properties of lithium manganese oxide are beneficial. Only when the content 
of calcium is higher, it is obviously adverse to electrochemical properties of lithium manganese oxide.

\section{References}

[1] Goodenough J B, Park K S. The Li-ion rechargeable battery: a perspective [J]. Journal of the American Chemical Society, 2013, 135(4): 1167-1176.

[2] Whittingham M S. Lithium batteries and cathode materials [J]. Chemical reviews, 2004, 104(10): 4271-4302.

[3] Ellis B L, Lee K T, Nazar L F. Positive electrode materials for Li-ion and Li-batteriest[J]. Chemistry of Materials, 2010, 22(3): 691-714.

[4] Rousse, G. and J Tarascon. Sulfate-based Polyanionic Compounds for Li-ion Batteries: Synthesis, Crystal Chemistry and Electrochemistry Aspects [J]. Chemistry of Materials, 2013.

[5] Hwang J T, Park S, Park C, et al. The Sintering Temperature Effect on Electrochemical Properties of $\mathrm{LiMn}_{2} \mathrm{O}_{4}[\mathrm{~J}]$. Bull. Korean Chem Soc, 2011, 32(11): 3952-3958.

[6] Zou Xing, Ma Li, Chen Gui. Research of different of manganese sources of spinel lithium manganese oxide performance impact [J]. Materials Science and Technology, 2011, 19 (5):p.131-134.

[7] Xing Zou, Chunlin Peng. Effects of $\mathrm{K}$ in $\mathrm{Mn}_{2} \mathrm{O}_{3}$ on the Electrochemical Performances of Spinel $\mathrm{Li}_{1.06} \mathrm{Mn}_{2} \mathrm{O}_{4}$ [C]. Industrial Technologies for Sustainable Development, 2013， 773: 611-616.

[8] Xing Zou, Haichao Xie, Gui Chen. Effect of Li Doping on Electrochemical Performances of Spinel $\mathrm{LiMn}_{2} \mathrm{O}_{4}$ prepared by $\mathrm{Mn}_{2} \mathrm{O}_{3}$ [C]. Elecric Technology and Civil Engineering, 2:690-693.

[9] Xiong L, Xu Y, Xiao X, et al. The effect of K-Ion on the electrochemical performance of spinel $\mathrm{LiMn}_{2} \mathrm{O}_{4}$ [J]. Electronic Materials Letters, 2015, 11(1): 138-142.

[10] Mandal, S., et al., High temperature co-doped $\mathrm{LiMn}_{2} \mathrm{O}_{4}$-based spinels. Structural, electrical, and electrochemical characterization [J]. Chemistry of materials, 2002. 14(4): p. 1598-1605.

[11] Pistoia G, Zane D, Zhang Y. Some Aspects of $\mathrm{LiMn}_{2} \mathrm{O}_{4}$ Electrochemistry in the 4 Volt Range [J]. Journal of The Electrochemical Society, 1995, 142(8): 2551-2557. 